\title{
Artificial Diets Modulate Infection Rates by Nosema ceranae in Bumblebees
}

\author{
Tamara Gómez-Moracho ${ }^{1, *}$, Tristan Durand ${ }^{1}$, Cristian Pasquaretta ${ }^{1} \mathbb{D}$, Philipp Heeb ${ }^{2}$ and Mathieu Lihoreau ${ }^{1}(\mathbb{D}$ \\ 1 Research Center on Animal Cognition (CRCA), Center for Integrative Biology (CBI), CNRS, \\ University Paul Sabatier, 31062 Toulouse, France; tristan.durand@protonmail.com (T.D.); \\ cristian.pasquaretta@univ-tlse.fr (C.P.); mathieu.lihoreau@univ-tlse3.fr (M.L.) \\ 2 Laboratoire Evolution et Diversité Biologique, UMR 5174 Centre National de la Recherche Scientifique, \\ Université Paul Sabatier, ENSFEA, 31062 Toulouse, France; philipp.heeb@univ-tlse3.fr \\ * Correspondence: tamara.gomez@univ-tlse3.fr
}

Citation: Gómez-Moracho, T.;

Durand, T.; Pasquaretta, C.; Heeb, P.; Lihoreau, M. Artificial Diets Modulate Infection Rates by Nosema ceranae in Bumblebees. Microorganisms 2021, 9, 158. https:// doi.org/10.3390/microorganisms 9010158

Received: 21 December 2020 Accepted: 8 January 2021 Published: 12 January 2021

Publisher's Note: MDPI stays neutral with regard to jurisdictional clai$\mathrm{ms}$ in published maps and institutional affiliations.

Copyright: $\odot 2021$ by the authors. Licensee MDPI, Basel, Switzerland. This article is an open access article distributed under the terms and conditions of the Creative Commons Attribution (CC BY) license (https:// creativecommons.org/licenses/by/ $4.0 /)$.

\begin{abstract}
Parasites alter the physiology and behaviour of their hosts. In domestic honey bees, the microsporidia Nosema ceranae induces energetic stress that impairs the behaviour of foragers, potentially leading to colony collapse. Whether this parasite similarly affects wild pollinators is little understood because of the low success rates of experimental infection protocols. Here, we present a new approach for infecting bumblebees (Bombus terrestris) with controlled amounts of $N$. ceranae by briefly exposing individual bumblebees to parasite spores before feeding them with artificial diets. We validated our protocol by testing the effect of two spore dosages and two diets varying in their protein to carbohydrate ratio on the prevalence of the parasite (proportion of PCR-positive bumblebees), the intensity of parasites (spore count in the gut and the faeces), and the survival of bumblebees. Overall, insects fed a low-protein, high-carbohydrate diet showed the highest parasite prevalence (up to $70 \%$ ) but lived the longest, suggesting that immunity and survival are maximised at different protein to carbohydrate ratios. Spore dosage did not affect parasite infection rate and host survival. The identification of experimental conditions for successfully infecting bumblebees with $N$. ceranae in the lab will facilitate future investigations of the sub-lethal effects of this parasite on the behaviour and cognition of wild pollinators.
\end{abstract}

Keywords: Bombus terrestris; Nosema ceranae; nutrition; experimental infection; survival analyses; PCR

\section{Introduction}

Bees face a large diversity of parasites and pathogens that negatively affect their physiology [1-3], behaviour, and cognition [4], altogether compromising the fitness of individuals and colonies [5]. The microsporidia Nosema ceranae is one of the most prevalent parasites of honey bees worldwide and a major cause of colony declines [2]. N. ceranae invades the epithelial cells of the honey bee midgut where it replicates [6,7]. At the physiological level, the parasite disrupts the carbohydrate [8,9] and lipid [10] metabolisms of the host. This causes energetic stress leading to increased consumption of sucrose solution [11-13], and alteration of gene expression in the brain [14], inhibition of the apoptosis of epithelial cells [15], and deregulation of immune responses [2]. At the behavioural level, infected honey bees start foraging earlier in life [16-18], exhibit more frequent but shorter foraging flights [19-21], show reduced homing abilities [22], and display lower olfactory learning performances $[23,24]$.

Recently, N. ceranae has also been identified in wild bee species (bumblebees [25-27], stingless bees [28,29]) as well as in some wasps [28] and butterflies [30]. Horizontal transmission to wild pollinators may occur through the contamination of flower pollen by infected honey bees. Parasite spillover is particularly concerning since many of these pollinators are solitary or live in small colonies [31], and therefore lack social immunity behaviours that allow honey bees to limit infection risks and combat parasites [32]. 
The effects of $N$. ceranae on wild pollinators have been best investigated in bumblebees. Recent studies suggest that $N$. ceranae impairs the cognitive abilities of bumblebees, potentially reducing the foraging performances of entire colonies [23,33]. However, the diversity of experimental infection protocols used in earlier studies, and their relatively low success rates (i.e., from $0 \%$ in $[33,34]$ to $66 \%$ in [35]) make it difficult to draw definitive conclusions and call for more robust standardised approaches. By contrast, $100 \%$ of infections are routinely reached in honey bee studies [36].

Published experimental infections with $N$. ceranae in bumblebees followed protocols applied in honey bees, but with no standardisation yet (see summary in Table 1). The age of insects, their level of starvation before exposure, the number of parasite spores to which they are exposed, and the way to inoculate them are all potentially important parameters that vary across current infection protocols $[37,38]$. Bumblebees were always exposed individually, and generally $N$. ceranae spores were provided in a solution delivered with a micropipette, although other approaches have been tested [39]. Parasite doses ranged from a few thousand to millions of spores per bee. Starvation duration varied from $30 \mathrm{~min}$ to $8 \mathrm{~h}$ and different ages were tested. Temperature conditions also varied from 25 or $33^{\circ} \mathrm{C}$. These different attempts led to contrasting results, especially concerning the infection rates. Thus far, only two studies achieved rates higher than $50 \%[27,35]$ on the basis of molecular analyses (Table 1). Longevity, as a measure of virulence of $N$. ceranae, is also highly variable with bumblebee survival rates ranging from 38\% [27] to 95\% [34] after 15 days of infection.

Another potentially important parameter, thus far unexplored, is the nutritional composition of diets provided to bumblebees after parasite exposure. Nutrition is a key mediator of host-parasite interactions [40] and should therefore be carefully controlled when developing standard infection procedures. Many insects increase their consumption of dietary protein to develop stronger immunological responses and combat parasites [41-43]. Increasing evidence indicates that bees given a choice of foods adjust their intake of nutrients to reach target levels maximising fitness traits. Although there is no direct demonstration that diet modifies the ability of bees to fight infections, bumblebees fed a low-protein diet have a reduced immune response [44]. Honey bees infected by Nosema apis [45] and N. ceranae [46-48] survived longer when provided protein rich pollen. Since protein consumption is needed for synthesising peptides in immune pathways [41,42,49], these results suggest that bees can adjust their nutrient intake for self-medication [50].

Here, we developed an experimental protocol to efficiently infect bumblebees with $N$. ceranae by briefly exposing individuals to controlled amounts of parasite spores and feeding them with artificial diets varying in their protein to carbohydrate ratios. We calibrated our approach by testing two spore dosages and two diets. We analysed parasite prevalence (proportion of infected bumblebees based on polymerase chain reactions, PCR), parasite intensity (spore counts in the gut), and host survival to identify the best conditions for infecting bumblebees at sub-lethal doses. To further analyse parasite infection, we analysed the faeces of bumblebees over 21 days in search of $N$. ceranae spores as evidence of parasite multiplication in the host. Finally, we performed a histological study of the ventriculi of bumblebees (where N. ceranae is found in honey bees [6,51]) in search of parasite forms inside the epithelial cells. 
Table 1. Summary of protocols developed to infect bumblebees (Bombus terrestris) with Nosema ceranae spores.

\begin{tabular}{|c|c|c|c|c|c|c|}
\hline Spores per Bumblebee & Starvation Duration & Age of Bumblebee & Parasite Exposure & Experimental Condition & $\begin{array}{l}\text { Rate of Infection } \\
\text { (Based on PCR) }\end{array}$ & Study \\
\hline 120,000 & $4 \mathrm{~h}$ & Unknown & $\begin{array}{l}\text { Micropipette } \\
30 \% \text { sugar-water }\end{array}$ & $\begin{array}{c}\text { Full colony; first } 2 \text { weeks: } \\
50 \% \text { sucrose solution }+ \text { pollen } \\
25{ }^{\circ} \mathrm{C}, 50-60 \% \mathrm{RH} \\
\text { Later on: field }\end{array}$ & $66 \%$ & [35] \\
\hline 6500 & $8 \mathrm{~h}$ & Unknown & $\begin{array}{l}\text { Hand-fed; } \\
40 \% \text { sucrose }\end{array}$ & $\begin{array}{c}\text { Groups of } 10 \\
40 \% \text { sucrose solution } \\
\text { N/A }\end{array}$ & $62 \%$ & [27] \\
\hline 100,000 & $30-60 \mathrm{~min}$ & 2 days old & $\begin{array}{l}\text { Individually in a Petri dish } \\
50 \% \text { sucrose solution }\end{array}$ & $\begin{array}{c}\text { Individually } \\
50 \% \text { sucrose solution + artificial pollen } \\
\text { N/A }\end{array}$ & $\begin{array}{c}34 \% \\
\text { No effect on survival }\end{array}$ & [39] \\
\hline 50,000 & $4 \mathrm{~h}$ & Newly hatched & $\begin{array}{c}\text { Fed individually } \\
\text { Sucrose/pollen solution }\end{array}$ & $\begin{array}{c}\text { Groups of } 10-25 ; 50 \%(w / v) \text { sucrose }+ \\
15 \%(w / v) \text { pollen } \\
33{ }^{\circ} \mathrm{C} \text { and } 55 \% \text { RH }\end{array}$ & $6.13 \%$ & {$[34]$} \\
\hline 180,000 & $2 \mathrm{~h}$ & Unknown & $\begin{array}{l}\text { Inoculated individually } \\
\text { Sucrose }(30 \%)\end{array}$ & $\begin{array}{c}\text { Groups of } 10 ; \\
50 \% \text { sucrose solution }+ \text { artificial pollen } \\
25^{\circ} \mathrm{C} \text { and } 50 \% \mathrm{RH}\end{array}$ & $3 \%$ & [23] \\
\hline $6500-5,000,000$ & $4 \mathrm{~h}$ & $\begin{array}{l}\text { Newly hatched, } 4 \text { weeks } \\
\text { old or mixed }\end{array}$ & $\begin{array}{c}\text { Fed individually } \\
\text { Sucrose-/pollen solution }\end{array}$ & $\begin{array}{c}\text { Groups of } 20 ; 50 \%(w / v) \text { sucrose }+15 \% \\
(w / v) \text { pollen } \\
33^{\circ} \mathrm{C} \text { and } 55 \% \mathrm{RH}\end{array}$ & $0 \%$ & [34] \\
\hline 130,000 & $2 \mathrm{~h}$ & Unknown & $\begin{array}{l}\text { Micropipette } \\
\text { Sucrose }(30 \%)\end{array}$ & $\begin{array}{c}\text { Microcolonies of } 10 ; 60 \% \text { sucrose solution } \\
+ \text { artificial pollen } \\
26^{\circ} \mathrm{C}, 55 \% \mathrm{RH}\end{array}$ & $0 \%$ & [33] \\
\hline
\end{tabular}




\section{Materials and Methods}

\subsection{Bees}

We ran 3 experiments with bumblebee workers (Bombus terrestris) of unknown age from 4 commercial colonies (Biobest, Belgium: experiment 1: 2 colonies, experiment 2: 1 colony, experiment 3: 1 colony). Before the experiments, we verified the absence of $N$. ceranae and other common parasites of bumblebees (N. bombi and Crithidia bombi) from a sample of 15 workers of each colony [27]. Diagnoses were performed in monoplex PCRs with the primers 218MITOC [52], Nbombi-SSU-J [53], and CB-ITS1 [54].

We used honey bees as a positive control of infection in experiment 1. Apis mellifera workers from unknown age came from a colony in our experimental apiary (University Paul Sabatier-Toulouse III, France) that tested free for N. ceranae and N. apis in a duplex PCR (primers 218MITOC and 321APIS, [52]), from a sample of 15 workers.

\subsection{Parasites}

We obtained N. ceranae spores from naturally infected honey bee colonies (Apis mellifera) at our experimental apiary. These colonies were spatially segregated from the Nosema-free colonies used for controls (see Section 2.1). We prepared spore solutions from samples of 15 honey bees as follows. We extracted the gut of the bees that we crushed in $15 \mathrm{~mL}$ of $\mathrm{dH}_{2} \mathrm{O}$. Once the presence of spores was verified using light microscopy $(\times 400)$, we checked the homogenates in a duplex PCR [52] to verify the presence of $N$. ceranae and the absence of $N$. apis (as spores of both parasites have similar morphologies; [55]). We then purified homogenates following a standard protocol [56]. Briefly, $1 \mathrm{~mL}$ of the honey bee gut homogenate was centrifuged at $5000 \mathrm{rpm}$ for $5 \mathrm{~min}$. The supernatant containing tissue debris was discarded and the pellet containing the spores was re-suspended in $0.5 \mathrm{~mL}$ of $\mathrm{dH}_{2} \mathrm{O}$ by vortexing. The sample was centrifuged and washed into distilled $\mathrm{H}_{2} \mathrm{O}$ two times more to obtain a spore solution of $85 \%$ purity [56]. To prepare the inoculum, we counted $N$. ceranae spores using an improved Neubauer haemocytometer [57] in a light microscope $(\times 400)$. Each sample was counted twice, and the total number of spores was averaged. We adjusted the final inoculum concentration to either 7500 spores $/ \mu \mathrm{L}$ or 15,000 spores $/ \mu \mathrm{L}$ in $20 \%(v / v)$ of sucrose solution. Spore solutions and inoculums were prepared no more than 1 week before the infections.

\subsection{Infections}

The day of infection, we isolated bumblebees in Petri dishes and starved them for $5 \mathrm{~h}$. Afterwards, inside the Petri dish, we delivered a drop of $20 \mu \mathrm{L}$ sucrose solution $(20 \% ; w / v)$ of the corresponding inoculum, containing either 150,000 (i.e., $150 \mathrm{~K}$ ) or 300,000 (i.e., $300 \mathrm{~K}$ ) spores, while control bumblebees only received sucrose solution. To make sure that all bumblebees were exposed to the same parasite dose, we only used bumblebees that drank the whole drop of sucrose in a maximum time of $2 \mathrm{~h}$.

We followed the same protocol to infect honey bees (experiment 1), except that honey bees were starved only for $2 \mathrm{~h}$, as preliminary observation showed this time is enough to elicit feeding. We coordinated both bumblebee and honey bee groups to perform the parasite exposure at the same time in both groups. Exposed honey bees received $150 \mathrm{~K}$ spores, and control 0 spores.

\subsection{Artificial Diets}

Diets were liquid solutions containing either a low protein to carbohydrate ratio (P/C 1:207.4, hereafter "low-protein diet") or a high protein to carbohydrate ratio (P/C 1:6.2, hereafter "high-protein diet"). The two diets contained a fixed total amount of nutrients $(\mathrm{P}+\mathrm{C}$ content of $170 \mathrm{~g} / \mathrm{L})$. Carbohydrates were supplied as sucrose (Euromedex, Strasbourg, France). Proteins consisted of a mixture of casein and whey (4:1) (Nutrimuscle, Paris, France). Both diets contained $0.5 \%$ of vitamin mixture for insects (Sigma, Darmstadt, Germany). Diets were delivered to bees in a gravity feeder, which consisted of a $1.5 \mathrm{~mL}$ 
Eppendorf tube with a hole at its basis through which the bees could insert their proboscis and ingest liquid food.

\subsection{Experiment 1. Does Diet Influence N. ceranae Infection?}

We tested the influence of diet and parasite dose on $N$. ceranae infection by analysing survival, parasite prevalence, and parasite loads in bumblebees. We used 300 bumblebee workers from 2 colonies. Bumblebees were exposed either to 150,000 (150 K) or 300,000 $(300 \mathrm{~K})$ spores of $N$. ceranae. Control individuals received only sucrose solution. Once the bumblebees had drunk the entire drop of sucrose (i.e., 272 out of 300 individuals), we allocated them to 1 of the 2 artificial diets, thereby generating 6 experimental groups of 44 to 47 individuals each (Table 2). We kept these bumblebees individually in a Petri dish with a hole $(1 \mathrm{~cm} \varnothing)$ on the top lid, in which we placed the gravity feeder containing 1 of the 2 diets. We replaced feeders with new feeders containing a fresh diet every day. We maintained the bumblebees in 2 identical incubators (Pol-Eko, Wodzisław Ślaski, Poland) at $26{ }^{\circ} \mathrm{C}$, with a $12 \mathrm{~h}$ light/12 h dark photoperiod for 21 days. Each incubator contained the same proportion of bees from the 6 experimental groups. The $9 \%$ of bumblebees that did not drink the sucrose solution were excluded from the experiment.

Table 2. Number of bumblebees exposed to N. ceranae that were PCR-positive and showed spores in their gut. The percentage of PCR-positive bumblebees relative to all exposed bumblebees and the percentage of bumblebees showing spores in their gut relative to all PCR-positive individuals are given in brackets.

\begin{tabular}{ccccc}
\hline Diet & Spore Dosage & Exposed & PCR-Positive & Showing Spores \\
\hline Low-protein & $150 \mathrm{~K}$ & 44 & $23(52.27 \%)$ & $7(30.4 \%)$ \\
& $300 \mathrm{~K}$ & 45 & $31(68.88 \%)$ & $9(29.03 \%)$ \\
\hline \multirow{2}{*}{ High-protein } & $150 \mathrm{~K}$ & 47 & $14(29.78 \%)$ & $4(28.5 \%)$ \\
& $300 \mathrm{~K}$ & 46 & $16(34.78 \%)$ & $6(37.5 \%)$ \\
\hline Total & & 182 & $84(46.15 \%)$ & $26(30.9 \%)$ \\
\hline
\end{tabular}

\subsubsection{Survival}

To account for survival, every day we recorded the number of dead bees and stored them at $-20{ }^{\circ} \mathrm{C}$ for later analyses. At the end of the experiment, we freeze-killed all surviving bumblebees and stored them at $-20{ }^{\circ} \mathrm{C}$.

\subsubsection{Parasite Prevalence}

We analysed the presence of $N$. ceranae in the gut of bumblebees by PCR (see example Figure 1A). We extracted the gut of each bumblebee and homogenised it in $\mathrm{dH}_{2} \mathrm{O}$. We vortexed a fraction of this homogenate with $2 \mathrm{~mm}$ glass beads (Labbox Labware, Barcelona, Spain) to break the parasite spores, and extracted genomic DNA using Proteinase $\mathrm{K}$ (20 mg/mL; Euromedex, Strasbourg, France) and $1 \mathrm{mM}$ of Tris-EDTA buffer $(\mathrm{pH}=8)$. In every round of extraction, we included a sample containing $N$. ceranae spores as a positive control. We amplified DNA with the primers 218MITOC specific for N. ceranae [52]. PCR reactions were carried out in 48-well microtitre plates in a S1000 Thermal Cycler (Biorad, Hercules, CA, USA) and contained $1.5 \mathrm{U}$ of Taq Polymerase (5 U/ $\mu \mathrm{L}$; MP Biomedicals, Santa Ana, CA, USA), $1 \times$ PCR Direct Loading Buffer (MP Biomedicals, Santa Ana, CA, USA), $0.4 \mu \mathrm{M}$ of each pair of primers [53], $200 \mu \mathrm{M}$ of dNTPs (Jena Biosciences, Jena, Germany), $0.48 \mu \mathrm{g} / \mu \mathrm{L}$ of BSA (Sigma, Darmstadt, Germany), and $2.5 \mu \mathrm{L}$ of DNA sample in a final volume of $25 \mu \mathrm{L}$. Thermal conditions were $94{ }^{\circ} \mathrm{C}$ for $2 \mathrm{~min}, 35$ cycles of $94{ }^{\circ} \mathrm{C}$ for $30 \mathrm{~s}, 61.8^{\circ} \mathrm{C}$ for $45 \mathrm{~s}$, and $72{ }^{\circ} \mathrm{C}$ for $2 \mathrm{~min}$, and a final step of $72{ }^{\circ} \mathrm{C}$ for $7 \mathrm{~min}$. We checked the length of PCR products (i.e., $218 \mathrm{pb}$ ) in a 1.2\% agarose gel electrophoresis stained with SYBR Safe DNA Stain (Edvotek, Washington, DC, USA). For each round of PCR, we ran negative controls in parallel to detect possible contaminations. 
A

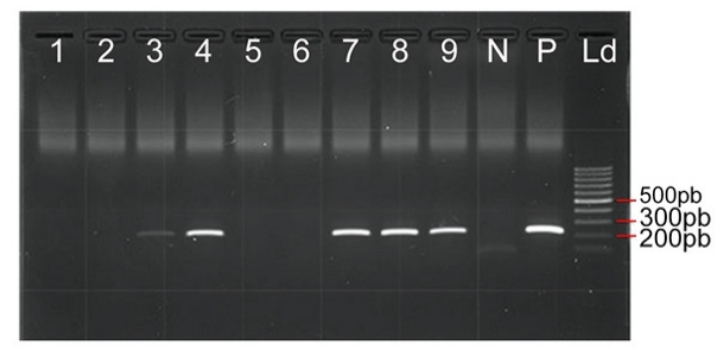

C

Low-protein diet $150 \mathrm{~K}$

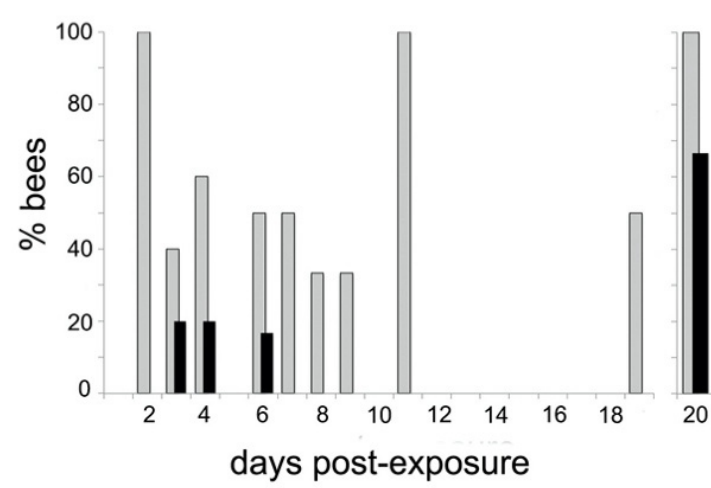

E

High-protein diet $150 \mathrm{~K}$

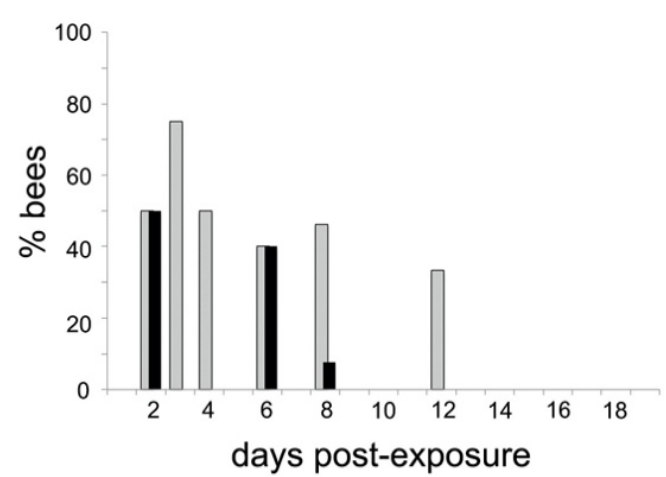

B

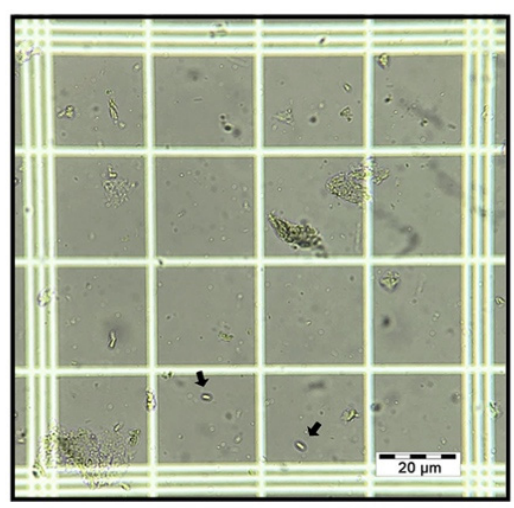

D

Low-protein diet 300K

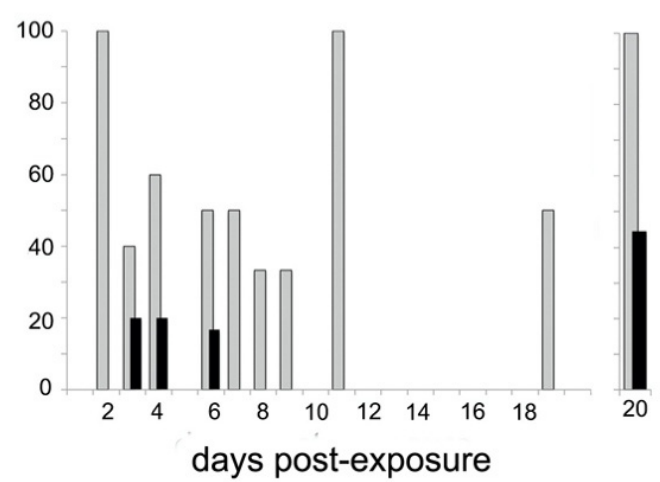

F

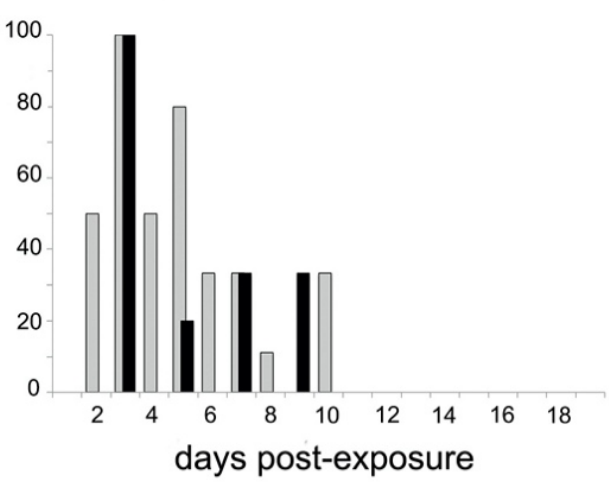

Figure 1. Parasite loads. (A) Example of agarose electrophoresis gel with negative (lanes 1, 2, 5, and 6) and positive (lanes 3 , 4, 7-9) bumblebees to N. ceranae determined by PCR. N: negative control of PCR; P: positive control of PCR; Ld: molecular size marker (100 pb). (B) Example of $N$. ceranae spores observed in an infected bumblebee (optical microscope, $\times 400)$. (C-F) Proportion of dead bumblebees at different days postexposure that were PCR-positive to N. ceranae (grey bars) and showed spores in their gut (black bars) for both diets (high- and low-protein diets) and spore dosages (150 K and $300 \mathrm{~K}$ ). Each group contained between 44 and 47 individuals. 


\subsubsection{Parasite Loads}

To further investigate the degree of infection of bumblebees, we assessed the number of spores present in the gut of bumblebees that were positive for N. ceranae in the PCR. We checked spores in the fraction of gut homogenates that was not vortexed. We counted the number of spores under a light microscope $(\times 400$; Leica, Wetzlar, Germany $)$ using a Neubauer chamber (Figure 1B). We also screened random samples of Nosema-negative PCR bumblebees to confirm the absence of parasite spores.

\subsection{Experiment 2. Do Bumblebees Evacuate N. ceranae Spores through Faeces?}

During infection, N. ceranae multiplies in the epithelial cells of the bees and new spores are released with the faeces, becoming a source of infection for new hosts [58]. Thus, the presence of $N$. ceranae spores in the faeces is a proxy for parasite infection. In order to evaluate whether bumblebees evacuate $N$. ceranae spores, we screened the faeces of bumblebees exposed to the parasite for 21 days. We exposed bumblebees to $300 \mathrm{~K} N$. ceranae spores (exposed group, $n=34$ ), or sucrose solution (control group, $n=33$ ) in a $20 \mu \mathrm{L}$ drop, as in experiment 1 . Here, we focused on the highest spore dose because it yielded the highest parasite prevalence in experiment 1 (Figure 1). We then used the bumblebees that drank the full drop (32 and 33 bees, respectively) to create 4 experimental groups: 2 groups in which bumblebees were fed the low-protein $\operatorname{diet}\left(\mathrm{N}_{\text {exposed }}=16, \mathrm{~N}_{\text {control }}=19\right)$, and 2 groups in which bumblebees were fed the high-protein $\operatorname{diet}\left(\mathrm{N}_{\text {exposed }}=16, \mathrm{~N}_{\text {control }}=14\right)$. We maintained the bumblebees as described in experiment 1, renewed the diets, and collected the faeces daily. For that, we rinsed each Petri dish with $500 \mu \mathrm{L}$ of sterile distilled water that we recovered later with a pipette and transferred it to a $1.5 \mathrm{~mL}$ Eppendorf tube. We stored the faeces samples at $-20^{\circ} \mathrm{C}$ until later analyses. When depositions were not found, we forced bumblebees to defecate by slightly pressing their abdomen with forceps. Immediately after each collection, we replaced the Petri dish with a clean one. Before any screening, we centrifuged each sample at $5000 \times \mathrm{g}$ for $5 \mathrm{~min}$, removed the supernatant, and adjusted the final volume to $200 \mu \mathrm{L}$ with $\mathrm{dH}_{2} \mathrm{O}$, thus standardising the volume of the samples. Next, we screened the samples in a light microscope (Leica DM750, Germany) and, if found, we counted N. ceranae spores in a Neubauer chamber. We then calculated the total number of spores released by bumblebees in $24 \mathrm{~h}$ by multiplying the number of spores $/ \mu \mathrm{L}$ by the volume of the sample (i.e., $200 \mu \mathrm{L}$ ).

\subsection{Experiment 3. Does N. ceranae Invade Bumblebee Gut Cells?}

Previous descriptions of $N$. ceranae in bumblebees are based on PCR diagnosis or identification of spores in gut homogenates (i.e., [27], this study), but there is still an absence of histological evidence confirming the establishment of the parasite inside the bumblebee gut epithelium [34]. We addressed this question by exposing bumblebees to $300 \mathrm{~K}$ spores. We then kept the bumblebees in microcolonies of 25 individuals in an experimental room set at $26^{\circ} \mathrm{C}$, where they fed the low-protein diet. Keeping bees in groups increases the chances that they get infected [59]. We focused on the low-protein diet on the basis of the observation that spores were found in faeces of bumblebees up to 19 days after exposure (experiment 2). By days 2, 9, and 16 after exposure, we sampled 2 exposed bumblebees and 2 controls for later analyses.

Histology samples were prepared as described elsewhere [6,60]. We dissected the digestive canal of each bumblebee with metallic forceps and separated the ventriculus from the rest of the tissue with a scalpel. We fixed each ventriculi in $4 \%$ formaldehyde (PanReac Applichem, Germany) for an overnight incubation $(\sim 18 \mathrm{~h})$ at $4{ }^{\circ} \mathrm{C}$. We then performed 3 washes on each tissue with phosphate buffer saline (PBS; $1 \times$ ) for a total time of $3 \mathrm{~h}$ and kept the tissues in 70\% ethanol. We embedded the tissues in paraffine and cut them in sections of $5 \mu \mathrm{m}$ in a microtome (Microm HM355; Thermo Scientific, Waltham, MA, USA). We stained sections with haematoxylin and eosin that we later checked in a light microscope (Leica, Wetzlar, Germany). We took pictures with Nikon digital camera DXM1200C in a Nikon Eclipse 80i microscope. 


\subsection{Statistical Analyses}

We performed all analyses in R v. 1.0.143 (R Development Core Team). Means are shown with standard errors (mean $\pm \mathrm{SE}$ ).

We tested the effects of diet, spore dosage, and their interaction on parasite prevalence (proportion of individuals infected after parasite exposure) using generalised linear models with a binomial error structure (binomial GLMs). We tested the effect of diet, spore dosage, and their interaction on the proportion of bees showing $N$. ceranae spores in their gut using a binomial GLM. We tested the effect of diet, spore dosage, and their interaction on parasite intensity (number of spores per bee) using a negative binomial GLM (because of the large over-dispersion of the data). We compared the parasite loads of individual bees that survived until the end of the experiment (day 21) and those that died before using a negative binomial GLM with a binary predictor (e.g., dead or alive at day 21) as a fixed effect. We tested the effect of diet on parasite intensity in bumblebee faeces using a negative binomial GLM. We fitted GLMs with binomial distribution errors using the glm function in the R package "stats". We fitted GLMs with a negative binomial error distribution using the glm.nb function in the R package "MASS" [61]. We tested all the models for interactions among predictors (e.g., diet, dosage, and PCR results) and removed all interactions that did not improve the fitting using the Akaike information criterion (AIC) for model comparison [62].

We analysed the survival of bumblebees using a Kaplan-Meier test curve with the function survfit in the R package "Survival" [63]. We analysed the effects of spore dosage, diet, infectious status, and their interactions using Cox proportional hazards regression models (function coxph in the R package "Survival"), followed by a Tukey post hoc test to account for pairwise comparisons. In all models, we included colony origin and incubator identity as random factors.

\section{Results}

\subsection{Experiment 1. Does Diet Influence N. ceranae Infection?}

We exposed bumblebees to two doses of $N$. ceranae and provided them two diets differing in their protein to carbohydrate ratio.

\subsubsection{Parasite Prevalence}

To assess parasite prevalence, we checked the presence of N. ceranae DNA in bumblebees by PCR (see example in Figure 1A). In total, $46.15 \%$ of the bumblebees exposed to N. ceranae were PCR-positive (Table 2), and $83.8 \%$ of the honey bees (119 out of 142 ), thus confirming that $N$. ceranae spores were infective. Note however that a proportion of non-exposed individuals (5.5\% bumblebees and 19.8\% honey bees) were also PCR-positive. This suggests that our colonies were not entirely free of parasites prior to the experiments or that horizontal cross-contamination occurred during the experiments. These bumblebees were excluded from further analyses.

Diets significantly influenced the proportion of bumblebees that became PCR-positive after exposure to the parasite (Table 2). A significantly larger number of bumblebees became PCR-positive when fed the low-protein diet in comparison with those fed the high-protein diet $\left(\mathrm{GLM}_{\text {binomial }}\right.$ : estimate $\left.=1.186( \pm 0.313), \mathrm{z}=3.79, p<0.001\right)$, irrespective of spore dosage $\left(\mathrm{GLM}_{\text {binomial }}\right.$ : estimate $\left.=0.4870( \pm 0.313), \mathrm{z}=1.503, p=0.133\right)$. Interestingly all the bumblebees that were fed the low-protein diet and that survived until day 21 were PCR-positive to N. ceranae (six bumblebees for $150 \mathrm{~K}$, nine bumblebees for $300 \mathrm{~K}$ ). By contrast, the only bumblebee that was fed the high-protein diet and that survived until day $21(300 \mathrm{~K})$ was PCR-negative.

\subsubsection{Parasite Loads}

To assess parasite loads, we screened the gut homogenates of dead PCR-positive bumblebees under a microscope for the presence of $N$. ceranae spores (Figure 1B). We observed N. ceranae spores in the gut of bumblebees from both diets (Figure 1C-F; see Table 
S1 for details). Comparing the presence of spores in bumblebees that did not die on the same day yielded information about the dynamics of spore evacuation and production. For the low-protein diet, we observed spores from day 3 to day 20 after exposure with $150 \mathrm{~K}$ spores (Figure 1C) and from day 4 to day 20 after exposure with $300 \mathrm{~K}$ spores (Figure 1D). Note, that there was no record of spores between day 8 and day 15, probably because of the low mortality rate of bumblebees on these days. For the high-protein diet, we observed spores from day 2 to 8 after exposure with $150 \mathrm{~K}$ spores (Figure 1E), and from day 3 to day 9 after exposure with $300 \mathrm{~K}$ spores (Figure $1 \mathrm{~F}$ ).

Overall, 30.9\% (26 out of 84 ) of the PCR-positive bumblebees showed N. ceranae spores in their gut (Table 2). This estimation of prevalence based on spore loads was lower than that based on PCR screening (Table 1). This suggests that we may have overlooked the presence of spores in samples with very low infection rate, as well as other intracellular stages of the parasite (e.g., meronts, sporonts) only detected by PCR. The proportion of bumblebees with spores in their gut was similar regardless of the diet (GLM binomial-diet: $_{\text {: }}$ estimate $=0.176( \pm 0.489), \mathrm{z}=0.36, p=0.718)$ and the spore dosage $\left(\mathrm{GLM}_{\text {binomial_spore dosage: }}\right.$ : estimate $=0.109( \pm 0.477), \mathrm{z}=0.23, p=0.819)$. Spore loads were highly variable across individuals, with an average of $183,655.8( \pm 36,017.48)$ spores per bumblebee. The spore dosage the bumblebees were exposed to had no effect on the spore loads found in their gut $\left(\mathrm{GLM}_{\text {negative-binomial }}\right.$ : estimate $\left.=-0.002( \pm 0.002), \mathrm{z}=-0.73, p=0.464\right)$. On the contrary, the diet had a significant effect on spore load $\left(G_{L} M_{\text {negative-binomial }}\right.$ : estimate $=1.294( \pm 0.347)$, $\mathrm{z}=3.73, p<0.001$ ), leading to higher amounts of spores in bumblebees fed the high-protein diet $(331,250 \pm 104,750.4$ spores per bee) than in bumblebees fed the low-protein diet $(91,406.25 \pm 22,851.56$ spores per bee $)$.

Considering bumblebees that were fed the low-protein diet and that survived until day 20 post exposure, only four out of six individuals exposed to $150 \mathrm{~K}$ spores $(75,000 \pm 26,615.5$ spores per bee; Figure 1C) and four out of nine individuals exposed to $300 \mathrm{~K}$ spores $(62,500 \pm 31,250$ spores per bee; Figure 1D) showed spores in their gut. These bumblebees showed similar spore loads than those fed the same diet but that died before day 20 post-exposure $\left(\mathrm{GLM}_{\text {negative-binomial: }}\right.$ estimate $\left.=-0.363( \pm 0.389), \mathrm{z}=-0.93, p=0.350\right)$.

\subsubsection{Survival}

To test the effect of spore dosage and diet on the survival of bumblebees, we analysed their longevity during the 20 days after parasite exposure. The infection status of each bumblebee was based on the PCR results. Overall, bumblebees fed the high-protein diet had lower survival than bumblebees fed the low-protein diet (Figure 2; Cox: estimate $=-0.75$ $( \pm 0.14), \mathrm{z}=-5.17, p<0.001)$. Bumblebees fed the high-protein diet (Figure 2A) showed similar mortality rate irrespective of spore dosage (Table 3) and infectious status (Table S2). By contrast, bumblebees fed the low-protein diet (Figure 2B) had a significantly reduced survival when exposed to $N$. ceranae spores than when non-exposed (Table 3). For this diet, $50 \%$ of exposed bumblebees died between days 6 and 7 post-exposure. This lethal time 50 $\left(\mathrm{LT}_{50}\right)$ was not reached for the non-exposed (control) bumblebees. Interestingly, in the lowprotein diet, PCR positive bumblebees tended to die faster than control bumblebees but survived significantly longer than PCR negative bumblebees (Figure 2B; Table 3). Therefore, both parasite exposure and infection (as measured by PCR) had negative effects on the survival of bumblebees maintained on the low-protein diet. 
A

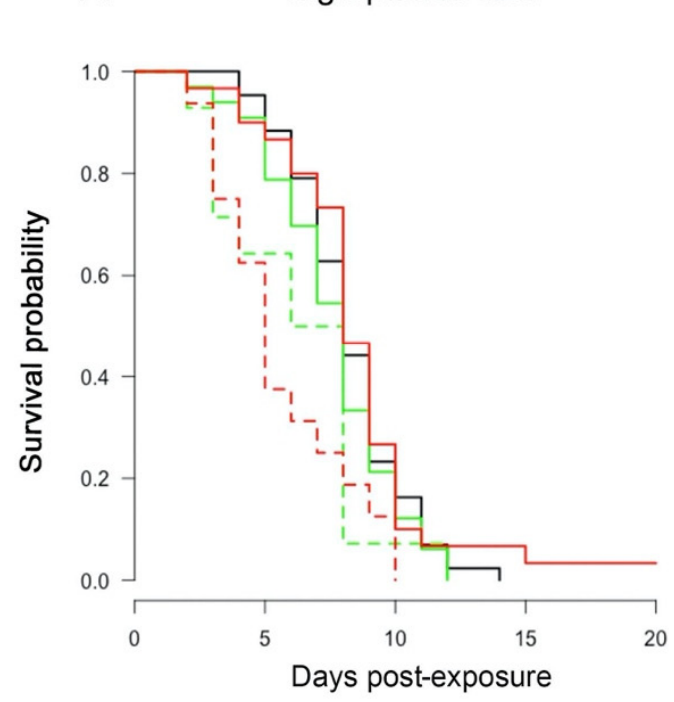

B Low-protein diet

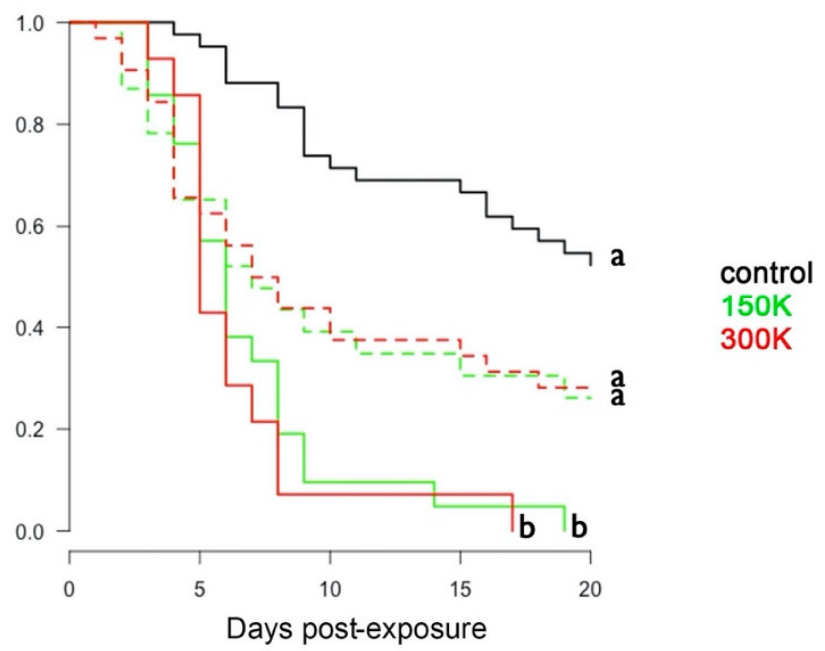

Figure 2. Survival analyses. Survival probability of bumblebees fed the high-protein diet (A) and the low-protein diet (B) for the different spore dosages (control, $150 \mathrm{~K}$, and $300 \mathrm{~K}$ ) across time. PCR-positive (dashed lines) and PCR-negative (solid lines) bumblebees are differentiated. Different letters associated with curves indicate statistical differences in survival $(p<0.05$; post hoc Tukey test after Cox regression model in a Kaplan-Meier test curve, see Table S2). Each group contained between 44 and 47 individuals.

Table 3. Cox regression model testing the effect of spore dosage on the survival of bumblebees for each diet.

\begin{tabular}{cccccc}
\hline Diet & Spore Dosage & Estimate & SE & $\mathbf{z}$ & $p$ \\
\hline High-protein & $150 \mathrm{~K}$ & 0.2766 & 0.2115 & 1.308 & 0.191 \\
& $300 \mathrm{~K}$ & 0.1440 & 0.2151 & 0.669 & 0.503 \\
\hline \multirow{2}{*}{ Low-protein } & $150 \mathrm{~K}$ & 1.2595 & 0.2792 & 4.511 & $<0.001$ \\
& $300 \mathrm{~K}$ & 1.1021 & 0.2808 & 3.925 & $<0.001$ \\
\hline
\end{tabular}

\subsection{Experiment 2. Do Bumblebees Evacuate N. ceranae Spores through Faeces?}

Intestinal pathogens are released with the faeces, which then constitute a source of infection for new hosts. Here, we investigated the presence of N. ceranae spores in bumblebee faeces as evidence of parasite infection. We collected the faeces of each bumblebee at least once, except for one exposed bumblebee that never had faeces spots in the Petri dish and never defecated after pressing his abdomen with forceps. This particular bumblebee was not considered for the analyses $(n=31)$. We screened a subset of faeces from control bumblebees on days $1,13,17,19$, and 21 post-exposure to verify the absence of spores (Table 4). We performed more screenings from day 13 post-exposure as we believe that the appearance of any spores in faeces after 10 days post exposure would reflect the releasing of new spores following parasite multiplication, and thus the success of the infection.

We did not find spores in any of the samples analysed from control bumblebees. Likewise, $32.22 \%$ of exposed bumblebees (10 out of 31 ) never showed spores, two of which survived the experiment. By contrast, we found spores in the faeces of $67.74 \%$ (21 out of 31) exposed bumblebees at least once (10 fed low-protein diet and 11 fed high-protein diet, Table 4). We detected spores as early as 1 day post-exposure and until day 19 in the low-protein diet but only until day 7 post-exposure in the high-protein diet, even if few bumblebees survived until the end of the experiment. 
Table 4. Number of faeces screened from exposed and control bumblebees in each diet at different days post-exposure. Number of faeces samples showing spores is shown in parentheses.

\begin{tabular}{lcccccccccccc}
\hline & \multicolumn{1}{c}{} & \multicolumn{1}{c}{ Days Post-Exposure } & \multicolumn{2}{c}{ Diet } \\
\cline { 2 - 12 } & $\mathbf{1}$ & $\mathbf{4}$ & $\mathbf{5}$ & $\mathbf{7}$ & $\mathbf{9}$ & $\mathbf{1 1}$ & $\mathbf{1 3}$ & $\mathbf{1 5}$ & $\mathbf{1 7}$ & $\mathbf{1 9}$ & $\mathbf{2 1}$ \\
\hline Exposed & $6(4)$ & $14(5)$ & $14(0)$ & $12(0)$ & $11(0)$ & $9(0)$ & $11(0)$ & $6(1)$ & $6(0)$ & $4(3)$ & $2(0)$ & Low P \\
Control & 2 & 0 & 0 & 0 & 0 & 0 & $13(1)$ & 0 & 8 & 7 & 7 \\
\hline Exposed & $8(8)$ & $14(3)$ & $15(2)$ & $12(1)$ & $12(0)$ & $9(0)$ & $8(0)$ & $8(0)$ & $7(0)$ & $5(0)$ & 0 & High P \\
Control & 1 & 0 & 0 & 0 & 0 & 0 & 0 & 0 & 3 & 2 & 2 \\
\hline
\end{tabular}

The number of spores excreted per $24 \mathrm{~h}$ in the faeces ranged from 500 to 85,000 $(17,462.96 \pm 4165.03)$ and did not differ between bumblebees fed the low-protein diet and those fed the high-protein diet $\left(20,500 \pm 7666.73\right.$ vs. $14,642 \pm 3906.33 ; \mathrm{GLM}_{\text {negative-binomial }}$ : estimate $=-0.336( \pm 0.466), \mathrm{z}=-0.721, p=0.471)$. The number of times we found spores in the faeces of the same bumblebee ranged from one to three. Sixteen bumblebees showed spores only once, at days 1 ( $n=9 ; 28,333 \pm 5830.95$ spores), 4 ( $n=5 ; 1250 \pm 322.74$ spores), 7 ( $n=1 ; 10,000$ spores), and 19 post-exposure $(n=1 ; 50,000$ spores). Identification of spores $24 \mathrm{~h}$ after feeding the parasite suggests that spores were not retained in the gut and therefore are not the result of an infection [34]. The other five spore-positive bumblebees showed spores at least twice. The two bumblebees fed the high-protein diet presented spores in their faeces on days 1 and 4 or 5 post-exposure, had a 2.5- and 3.3-fold more spores in the second sampling (i.e., 2000 to 5000 , and 6000 to 20,000 spores, respectively). Likewise, a bumblebee fed the low-protein diet showed 4.25-fold more spores on day 19 (i.e., 85,000 spores) than on day 15 (20,000 spores). On the contrary, two bumblebees fed the low-protein diet showed a reduction on spore loads by 0.25 -fold between the two sampling days (i.e., days 1 and 4, 4000 to 1000 spores; days 4 and 19, 2000 to 500 spores, respectively). Evidence of spores twice in the same individual, after several days of exposure and with an increase in the number of spores relative to the first sample analysed, suggests that the parasite was able to multiply.

\subsection{Experiment 3. Does N. ceranae Invade Bumblebee Gut Cells?}

In honey bees, N. ceranae invades the epithelial cells where it multiplies [6]. Given our observation of spores in bumblebee guts and faeces 20 days after parasite exposure, we performed histological analysis to identify parasitic forms inside the epithelial cells of the ventriculi of bumblebees as evidence of parasite infection. We analysed six bumblebees exposed to $300 \mathrm{~K}$ spores of $N$. ceranae (two bumblebees at days 2, 9, and 16 post exposure) and three unexposed controls, all maintained on a low-protein diet. We did not find any evidence of parasite infection in any of these bumblebees (see examples in Figure 3). Epithelium of exposed bumblebees did not show signs of damage (i.e., lyses of epithelial cells) and there were no parasitic forms inside the cells. 


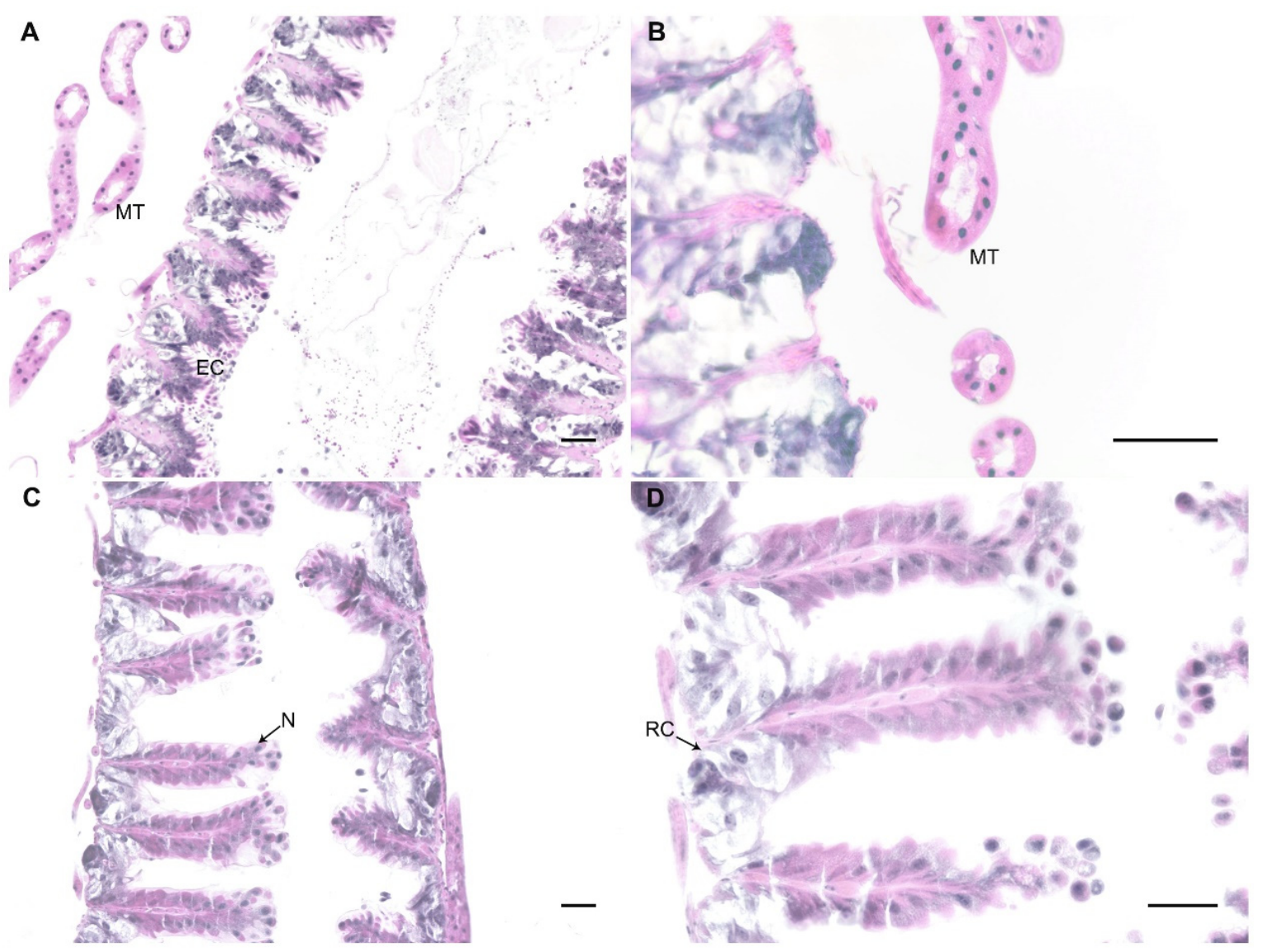

Figure 3. Examples of midgut sections under the light microscope of a portion of the ventriculus of control (A) and exposed bumblebees at days 9 (B) and 16 (C,D) post-exposure. No evidence of parasitic form was observed in the epithelium (EC), nor in the Malpighian tubules (MT). N: nuclei, RC: regenerative cells. Haematoxylin and eosin staining. Bar scale $=25 \mu \mathrm{m}$.

\section{Discussion}

Several recent studies suggest that $N$. ceranae negatively affects bee behaviour and cognition, with dramatic consequences for colony growth and survival $[23,24]$. In bumblebees, these results remain difficult to interpret due to the low efficiency of experimental infection protocols. Here, we exploited recent insight into the nutritional ecology of bees [64-66] to develop a method to infect bumblebees with $N$. ceranae. We identified key effects of diet composition on bumblebee infection rates, survival, and spore production, indicating a complex interaction between diet, parasite development, and host health.

Overall, $46 \%$ of the bumblebees exposed to N. ceranae spores were PCR-positive, a percentage that increased to up to $70 \%$ when only considering bumblebees that were exposed to $300 \mathrm{~K}$ spores and maintained on a low-protein, high-carbohydrate diet. These levels of prevalence are similar to those obtained by Graystock et al. [27] (62\% infection rate) with a 20 to 45 times lower infection dose (measured in naturally infected colonies: 6500 spores / bee), and Botías et al. [35] (66\% infection rate) with a dose of 130,000 spores per bee. In both studies, the authors administered the parasite with a micropipette directly into the bee mouth parts. These rates of prevalence are higher than all previous studies where bumblebees were exposed to an order of at least $10^{5}$ spores per bee, either delivered as a drop of solution in a Petri dish [39] or directly fed to bumblebees [23,33,34].

We did not find any clear effect of parasite dosage ( $150 \mathrm{~K}$ or $300 \mathrm{~K}$ spores per bee) on prevalence and survival. Comparing our results to that of previous studies does not indicate such effect either, which suggests that above a certain concentration of parasite spores (e.g., 6500 spores /bee in [27]), parasite dosage is not an important factor determining the success of infection. In contrast, we found a strong effect of diet on parasite prevalence 
and spore loads in bumblebee guts. Pollen intake affects honey bee physiology and tolerance to $N$. ceranae $[67,68]$. Using artificial diets with controlled amounts of protein and carbohydrates, we demonstrated that food macronutrient balance substantially influences both the infection rate and the survival of bumblebees. More bumblebees were PCRpositive when fed the low-protein, high-carbohydrate diet, suggesting that different blends of nutrients differently affect host susceptibility or parasite physiology (but see [46]). The digestion of the different macronutrients in the bumblebee gut, whose microbiota is mostly composed of sugar-fermenting bacteria [69], may lead to changes in the gut environment that could favour the parasite germination, such as shifts in $\mathrm{pH}$ [70]. Furthermore, because $N$. ceranae exploits the metabolism of carbohydrates to obtain energy from its host [8], a higher carbohydrate consumption by infected bumblebees may benefit the establishment of N. ceranae. Like previous studies on honey bees that showed that the supplement of pollen in diet increases parasite intensity $[46,68,71]$, we found that bumblebees with access to higher amounts of protein show higher spore loads in their gut. This suggests that proteins benefit the replication of the parasite.

The effect of diet was also evident in bumblebee survival. N. ceranae reduced the survival of bumblebees, specifically in the low-protein, high-carbohydrate diet, where the mortality rate increased by day 3 post-exposure. This result is consistent with the time described for N. ceranae to produce new spores in the honey bee gut [6]. Similarly to Graystock et al. [27], we found that most of the bumblebees that tested positive for $N$. ceranae in PCR $(67.5 \%)$ died without showing spores in their gut, suggesting that the parasite was not able to complete its cycle at a detectable level (i.e., produce new spores). The absence of parasite spores in the gut of bumblebees that died at different times could reflect the ability of bumblebees to clear the parasite. The fact that Nosema-positive bumblebees (i.e., PCR) fed the low-protein, high-carbohydrate diet survived longer than exposed non-positive bumblebees fed the same diet suggests that the mechanisms allowing parasite clearance incur a higher metabolic cost, here manifested as a reduction of bumblebee lifespan. This cost can be linked to the activation of the immune response against $N$. ceranae, in which several immune-related genes are activated in bumblebees when fed this parasite [35]. Alternatively, interactions between bumblebees and N. ceranae are recent or rare, and parasites were only able to establish themselves in hosts that for an unknown reason had greater longevity.

We found spores in the faeces of bumblebees fed N. ceranae. Some bumblebees only excreted spores with their faeces once, and on the following day after feeding the parasite. Recently, Gisder et al. [34] showed that N. ceranae spores travel faster in the digestive tract of bumblebees than in honey bees, which could prevent infection in bumblebees. It is then possible that these spores, ingested by bumblebees at the beginning of the experiment, were fast released and did not produce any infection, as no other spores were observed in samples from the same bumblebees later in the experiment. However, when the excretion of spores happens later in the experiment, i.e., from day 4 or afterwards, it may indicate a possible establishment of $N$. ceranae in the bumblebees and its multiplication, especially in those bumblebees where there was an increase in the number of spore counts (i.e., 20,000 vs. 85,000 spores in days 15 and 19, respectively).

Surprisingly, in the histological analyses, we did not find evidence of parasite infection in the bumblebee ventriculi nor the Malpighi tubules. This suggests that $N$. ceranae does not invade the gut epithelium in bumblebees as it does in A. mellifera, where it presents a high tropism [51]. Alternatively, N. ceranae might invade other tissues where it could develop. Graystok et al. [27] found molecular evidence for the presence of N. ceranae in the fat body of bumblebees, suggesting the migration of $N$. ceranae from the gut to this organ [27]. The fat body is also invaded by the microsporidia Nosema bombi in bumblebee infections [72,73]. However, further analyses are needed to test this hypothesis.

The fact that bumblebees showed low parasite prevalence but died faster when fed a high-protein, low-carbohydrate diet suggests that immunity and lifespan are maximised at different nutritional balances. Several studies show how an animal's diet can differ- 
ently influence the expression of key life-history traits, forcing the animal to the trade-off between optimising multiple traits simultaneously (e.g., [74-76]). In insects, lifespan is typically enhanced on high-carbohydrate diets whereas reproduction is maximised on high-protein diets (fruit flies [77-81], crickets [82]). Immunity and reproduction also display differences in nutritional requirements (as shown in fruit flies [40,83], decorated crickets [76], cotton leafworm [43]). Honey bees survive longer on high-carbohydrate diets [84], and pollen (the main source of protein) favours the survival of individuals infected with $N$. ceranae $[46,68,71,85]$. Whether sterile bumblebee workers trade-off between over-ingesting protein and under-ingesting carbohydrates in order to reduce parasite establishment at the expense of a shorter lifespan is an open question. In these social insects, such individual strategy may reduce the risks of contamination of other workers within the colony [50].

Developing standard protocols to characterise the sublethal effects of parasites and pathogens on bees has become a major challenge for understanding bee population declines [4]. Here, we demonstrated that diet is key in determining infection rates of bumblebees exposed to $N$. ceranae. The highest infection rates and the longest survivals were obtained with a high-carbohydrate, low-protein diet, thereby providing ideal conditions for investigating the potential effects of $N$. ceranae on bee behaviour and cognition. Other parameters, not tested here, may also be of importance and investigated in future studies. For instance, both our study and Graystock et al. [27] starved bumblebees for at least $5 \mathrm{~h}$ before to parasite exposure, which may have increased the probability of parasite establishment. Variations in the age of the bumblebee tested may also explain some of these differences. In the only study that controlled for age, Fürst et al. [39] infected 2-day-old bumblebees (post-eclosion from the pupa) and obtained a lower infection rate than the one obtained in this study and found no effect on bumblebee mortality, suggesting that young bumblebees are less susceptible to the parasite. Finally, we cannot exclude differences in the virulence of the $N$. ceranae strains used for experimental infection across studies (but see [86]). We hope that our infection protocol will stimulate further studies on the interactions between $N$. ceranae and bumblebees in order to better assess the risks this emergent parasite represents for wild pollinators.

Supplementary Materials: The following are available online at https:/ / www.mdpi.com/2076-2 607/9/1/158/s1: Table S1: Number of bumblebees positive to N. ceranae in a PCR and showing spores at different days post-exposure per spore dosage and diet treatment. LP: low-protein diet; HP: high-protein diet. Table S2: Tukey post hoc test to account for pairwise comparisons between bumblebees in different diets and spore treatments. Groups are defined by diet, dosage, and infection. Diet: C (low-protein), P (high-protein). Dosage: 0, 150, 300. Infection: 0 (not infected), 1 (infected).

Author Contributions: Conceptualisation, T.G.-M. and M.L.; investigation, T.G.-M. and T.D.; formal analysis, T.G.-M. and C.P.; writing—original draft preparation, T.G.-M.; writing-review and editing, T.G.-M., C.P., P.H. and M.L.; visualisation, T.G.-M.; supervision, T.G.-M. and M.L.; funding acquisition, T.G.-M. and M.L. All authors have read and agreed to the published version of the manuscript.

Funding: T.G.-M. was funded by a postdoctoral fellowship from the Fyssen Foundation. P.H. was funded by the "Laboratoire d'Excellence (LABEX)" TULIP (ANR-10-LABX-41). T.D., C.P. and M.L. were funded by a grant from the Agence Nationale de la Recherche to ML (ANR-16-CE02-0002-01).

Institutional Review Board Statement: Not applicable.

Informed Consent Statement: Not applicable.

Data Availability Statement: Data is contained within the article or as Supplementary Material.

Acknowledgments: We thank Pascale Belenguer, Nathalie Escalas, Lucie Hotier, Audrey Dussutour, and Enikö Csata for their help and advice.

Conflicts of Interest: The authors declare no conflict of interest. 


\section{References}

1. Schmid-Hempel, P. On the evolutionary ecology of host-parasite interactions: Addressing the question with regard to bumblebees and their parasites. Naturwissenschaften 2001, 88, 147-158. [CrossRef] [PubMed]

2. Martín-Hernández, R.; Bartolomé, C.; Soroker, V.; Higes, M.; Chejanovsky, N.; Le Conte, Y.; Dalmon, A.; Dussaubat, C.; GarcíaPalencia, P.; Meana, A.; et al. Nosema ceranae in Apis mellifera: A 12 years post detection perspective. Environ. Microbiol. 2018, 20, 1302-1329. [CrossRef] [PubMed]

3. Hristov, P.; Shumkova, R.; Palova, N.; Neov, B. Factors Associated with Honey Bee Colony Losses: A Mini-Review. Vet. Sci. 2020, 7, 166. [CrossRef] [PubMed]

4. Gómez-Moracho, T.; Heeb, P.; Lihoreau, M. Effects of parasites and pathogens on bee cognition. Ecol. Èntomol. 2017, 42, 51-64. [CrossRef]

5. Klein, S.; Cabirol, A.; Devaud, J.-M.; Barron, A.B.; Lihoreau, M. Why Bees Are So Vulnerable to Environmental Stressors. Trends Ecol. Evol. 2017, 32, 268-278. [CrossRef]

6. Higes, M.; García-Palencia, P.; Martín-Hernández, R.; Meana, A. Experimental infection of Apis mellifera honeybees with Nosema ceranae (Microsporidia). J. Invertebr. Pathol. 2007, 94, 211-217. [CrossRef]

7. García-Palencia, P.; Martín-Hernández, R.; González-Porto, A.-V.; Marin, P.; Meana, A.; Higes, M. Natural infection by Nosema ceranae causes similar lesions as in experimentally infected caged-worker honey bees (Apis mellifera). J. Apic. Res. 2010, 49, 278-283. [CrossRef]

8. Mayack, C.; Naug, D. Energetic stress in the honeybee Apis mellifera from Nosema ceranae infection. J. Invertebr. Pathol. 2009, 100, 185-188. [CrossRef]

9. Aliferis, K.A.; Copley, T.; Jabaji, S. Gas chromatography-mass spectrometry metabolite profiling of worker honey bee (Apis mellifera L.) hemolymph for the study of Nosema ceranae infection. J. Insect Physiol. 2012, 58, 1349-1359. [CrossRef]

10. Li, W.; Chen, Y.; Cook, S.C. Chronic Nosema ceranae infection inflicts comprehensive and persistent immunosuppression and accelerated lipid loss in host Apis mellifera honey bees. Int. J. Parasitol. 2018, 48, 433-444. [CrossRef]

11. Aufauvre, J.; Biron, D.G.; Vidau, C.; Fontbonne, R.; Roudel, M.; Diogon, M.; Viguès, B.; Belzunces, L.P.; Delbac, F.; Blot, N. Parasite-insecticide interactions: A case study of Nosema ceranae and fipronil synergy on honeybee. Sci. Rep. 2012, 2, 326. [CrossRef] [PubMed]

12. Alaux, C.; Brunet, J.-L.; Dussaubat, C.; Mondet, F.; Tchamitchian, S.; Cousin, M.; Brillard, J.; Baldy, A.; Belzunces, L.P.; Le Conte, Y. Interactions between Nosema microspores and a neonicotinoid weaken honeybees (Apis mellifera). Environ. Microbiol. 2010, 12, 774-782. [CrossRef] [PubMed]

13. Martín-Hernández, R.; Botías, C.; Barrios, L.; Martínez-Salvador, A.; Meana, A.; Mayack, C.; Higes, M. Comparison of the energetic stress associated with experimental Nosema ceranae and Nosema apis infection of honeybees (Apis mellifera). Parasitol. Res. 2011, 109, 605-612. [CrossRef] [PubMed]

14. Holt, H.L.; Aronstein, K.; Grozinger, C.M. Chronic parasitization by Nosema microsporidia causes global expression changes in core nutritional, metabolic and behavioral pathways in honey bee workers (Apis mellifera). BMC Genom. 2013, 14, 799. [CrossRef] [PubMed]

15. Martín-Hernández, R.; Higes, M.; Sagastume, S.; Juarranz, Á.; Dias-Almeida, J.; Budge, G.E.; Meana, A.; Boonham, N. Microsporidia infection impacts the host cell's cycle and reduces host cell apoptosis. PLoS ONE 2017, 12, e0170183. [CrossRef] [PubMed]

16. Higes, M.; Martín-Hernández, R.; Garrido-Bailón, E.; González-Porto, A.V.; García-Palencia, P.; Meana, A.; Del Nozal, M.J.; Mayo, R.; Bernal, J.L. Honeybee colony collapse due to Nosema ceranaein professional apiaries. Environ. Microbiol. Rep. 2009, 1, 110-113. [CrossRef] [PubMed]

17. Goblirsch, M.; Huang, Z.Y.; Spivak, M. Physiological and Behavioral Changes in Honey Bees (Apis mellifera) Induced by Nosema ceranae Infection. PLoS ONE 2013, 8, e58165. [CrossRef]

18. Perry, C.J.; Søvik, E.; Myerscough, M.R.; Barron, A.B. Rapid behavioral maturation accelerates failure of stressed honey bee colonies. Proc. Natl. Acad. Sci. USA 2015, 112, 3427-3432. [CrossRef]

19. Kralj, J.; Fuchs, S. Nosema sp. influences flight behavior of infected honey bee (Apis mellifera) foragers. Apidologie 2009, 41, 21-28. [CrossRef]

20. Dosselli, R.; Grassl, J.; Carson, A.; Simmons, L.W.; Baer, B. Flight behaviour of honey bee (Apis mellifera) workers is altered by initial infections of the fungal parasite Nosema apis. Sci. Rep. 2016, 6, 36649. [CrossRef]

21. Dussaubat, C.; Maisonnasse, A.; Crauser, D.; Beslay, D.; Costagliola, G.; Soubeyrand, S.; Kretzchmar, A.; Le Conte, Y. Flight behavior and pheromone changes associated to Nosema ceranae infection of honey bee workers (Apis mellifera) in field conditions. J. Invertebr. Pathol. 2013, 113, 42-51. [CrossRef] [PubMed]

22. Wolf, S.; McMahon, D.P.; Lim, K.S.; Pull, C.D.; Clark, S.J.; Paxton, R.J.; Osborne, J.L. So Near and Yet So Far: Harmonic Radar Reveals Reduced Homing Ability of Nosema Infected Honeybees. PLoS ONE 2014, 9, e103989. [CrossRef]

23. Piiroinen, S.; Goulson, D. Chronic neonicotinoid pesticide exposure and parasite stress differentially affects learning in honeybees and bumblebees. Proc. R. Soc. B Biol. Sci. 2016, 283, 20160246. [CrossRef] [PubMed]

24. Gage, S.L.; Kramer, C.; Calle, S.; Carroll, M.; Heien, M.; DeGrandi-Hoffman, G. Nosema ceranae parasitism impacts olfactory learning and memory and neurochemistry in honey bees (Apis mellifera). J. Exp. Biol. 2017, 221, jeb161489. [CrossRef] [PubMed] 
25. Plischuk, S.; Martín-Hernández, R.; Prieto, L.; Lucía, M.; Botías, C.; Meana, A.; Abrahamovich, A.H.; Lange, C.; Higes, M. South American native bumblebees (Hymenoptera: Apidae) infected by Nosema ceranae (Microsporidia), an emerging pathogen of honeybees (Apis mellifera). Environ. Microbiol. Rep. 2009, 1, 131-135. [CrossRef] [PubMed]

26. Li, J.; Chen, W.; Wu, J.; Peng, W.; An, J.; Schmid-Hempel, P.; Schmid-Hempel, R. Diversity of Nosema associated with bumblebees (Bombus spp.) from China. Int. J. Parasitol. 2012, 42, 49-61. [CrossRef]

27. Graystock, P.; Yates, K.; Darvill, B.; Goulson, D.; Hughes, W.O.H. Emerging dangers: Deadly effects of an emergent parasite in a new pollinator host. J. Invertebr. Pathol. 2013, 114, 114-119. [CrossRef]

28. Porrini, M.P.; Porrini, L.P.; Garrido, P.M.; de Melo e Silva Neto, C.; Porrini, D.P.; Muller, F.; Nuñez, L.A.; Alvarez, L.; Iriarte, P.F.; Eguaras, M.J. Nosema ceranae in South American Native Stingless Bees and Social Wasp. Microb. Ecol. 2017, 74, 761-764. [CrossRef]

29. Purkiss, T.; Lach, L. Pathogen spillover from Apis mellifera to a stingless bee. Proc. R. Soc. B Biol. Sci. 2019, $286,20191071$. [CrossRef]

30. Malysh, J.M.; Ignatieva, A.N.; Artokhin, K.S.; Frolov, A.N.; Tokarev, Y.S. Natural infection of the beet webworm Loxostege sticticalis L. (Lepidoptera: Crambidae) with three Microsporidia and host switching in Nosema ceranae. Parasitol. Res. 2018, 117, 3039-3044. [CrossRef]

31. Michener, C.D. The Bees of the World, 2nd ed.; Johns Hopkins University Press: Baltimore, MA, USA, 2007; ISBN 978-0-8018-8573-0.

32. Cremer, S.; Armitage, S.A.O.; Schmid-Hempel, P. Social immunity. Curr. Biol. 2007, 17, R693-R702. [CrossRef] [PubMed]

33. Piiroinen, S.; Botías, C.; Nicholls, E.; Goulson, D. No effect of low-level chronic neonicotinoid exposure on bumblebee learning and fecundity. PeerJ 2016, 4. [CrossRef] [PubMed]

34. Gisder, S.; Horchler, L.; Pieper, F.; Schüler, V.; Šima, P.; Genersch, E. Rapid Gastrointestinal Passage May Protect Bombus terrestris from Becoming a True Host for Nosema ceranae. Appl. Environ. Microbiol. 2020, 86. [CrossRef] [PubMed]

35. Botías, C.; Jones, J.C.; Pamminger, T.; Bartomeus, I.; Hughes, W.O.H.; Goulson, D. Multiple stressors interact to impair the performance of bumblebee (Bombus terrestris) colonies. J. Anim. Ecol. 2020, 1365-2656. [CrossRef]

36. Roberts, K.E.; Hughes, W.O.H. Horizontal transmission of a parasite is influenced by infected host phenotype and density. Parasitology 2015, 142, 395-405. [CrossRef]

37. Rutrecht, S.T.; Klee, J.; Brown, M.J.F. Horizontal transmission success of Nosema bombi to its adult bumble bee hosts: Effects of dosage, spore source and host age. Parasitology 2007, 134, 1719-1726. [CrossRef]

38. Urbieta-Magro, A.; Higes, M.; Meana, A.; Barrios, L.; Martín-Hernández, R. Age and Method of Inoculation Influence the Infection of Worker Honey Bees (Apis mellifera) by Nosema ceranae. Insects 2019, 10, 417. [CrossRef]

39. Fürst, M.; McMahon, D.P.; Osborne, J.L.; Paxton, R.J.; Brown, M.J.F. Disease associations between honeybees and bumblebees as a threat to wild pollinators. Nat. Cell Biol. 2014, 506, 364-366. [CrossRef]

40. Ponton, F.; Wilson, K.; Cotter, S.C.; Raubenheimer, D.; Simpson, S.J. Nutritional Immunology: A Multi-Dimensional Approach. PLoS Pathog. 2011, 7, e1002223. [CrossRef]

41. Lee, K.P.; Cory, J.S.; Wilson, K.; Raubenheimer, D.; Simpson, S.J. Flexible diet choice offsets protein costs of pathogen resistance in a caterpillar. Proc. R. Soc. B Boil. Sci. 2005, 273, 823-829. [CrossRef]

42. Povey, S.; Cotter, S.C.; Simpson, S.J.; Wilson, K. Dynamics of macronutrient self-medication and illness-induced anorexia in virally infected insects. J. Anim. Ecol. 2013, 83, 245-255. [CrossRef] [PubMed]

43. Cotter, S.C.; Simpson, S.J.; Raubenheimer, D.; Wilson, K. Macronutrient balance mediates trade-offs between immune function and life history traits. Funct. Ecol. 2010, 25, 186-198. [CrossRef]

44. Brunner, F.S.; Schmid-Hempel, P.; Barribeau, S.M. Protein-poor diet reduces host-specific immune gene expression in Bombus terrestris. Proc. R. Soc. B Boil. Sci. 2014, 281, 20140128. [CrossRef] [PubMed]

45. Rinderer, T.E.; Elliott, K.D. Worker Honey Bee Response to Infection with Nosema apis: Influence of Diet. J. Econ. Entomol. 1977, 70, 431-433. [CrossRef]

46. Jack, C.J.; Uppala, S.S.; Lucas, H.M.; Sagili, R.R. Effects of pollen dilution on infection of Nosema ceranae in honey bees. J. Insect Physiol. 2016, 87, 12-19. [CrossRef]

47. Tritschler, M.; Vollmann, J.J.; Yañez, O.; Chejanovsky, N.; Crailsheim, K.; Neumann, P. Protein nutrition governs within-host race of honey bee pathogens. Sci. Rep. 2017, 7, 14988. [CrossRef]

48. Porrini, M.P.; Sarlo, E.G.; Medici, S.K.; Garrido, P.M.; Porrini, D.P.; Damiani, N.; Eguaras, M.J. Nosema ceranae development in Apis mellifera: Influence of diet and infective inoculum. J. Apic. Res. 2011, 50, 35-41. [CrossRef]

49. Mason, P.A.; Smilanich, A.M.; Singer, M.S. Reduced consumption of protein-rich foods follows immune challenge in a polyphagous caterpillar. J. Exp. Biol. 2014, 217, 2250-2260. [CrossRef]

50. Poissonnier, L.-A.; Lihoreau, M.; Gomez-Moracho, T.; Dussutour, A.; Buhl, J. A theoretical exploration of dietary collective medication in social insects. J. Insect Physiol. 2018, 106, 78-87. [CrossRef]

51. Higes, M.; García-Palencia, P.; Urbieta, A.; Nanetti, A.; Martín-Hernández, R. Nosema apis and Nosema ceranae Tissue Tropism in Worker Honey Bees (Apis mellifera). Vet. Pathol. 2019, 57, 132-138. [CrossRef]

52. Martín-Hernández, R.; Meana, A.; Prieto, L.; Salvador, A.M.; Garrido-Bailón, E.; Higes, M. Outcome of Colonization of Apis mellifera by Nosema ceranae. Appl. Environ. Microbiol. 2007, 73, 6331-6338. [CrossRef] [PubMed]

53. Klee, J.; Tay, W.T.; Paxton, R.J. Specific and sensitive detection of Nosema bombi (Microsporidia: Nosematidae) in bumble bees (Bombus spp.; Hymenoptera: Apidae) by PCR of partial rRNA gene sequences. J. Invertebr. Pathol. 2006, 91, 98-104. [CrossRef] [PubMed] 
54. Schmid-Hempel, R.; Tognazzo, M. Molecular Divergence Defines Two Distinct Lineages of Crithidia bombi (Trypanosomatidae), Parasites of Bumblebees. J. Eukaryot. Microbiol. 2010, 57, 337-345. [CrossRef] [PubMed]

55. Fries, I.; Martin, R.; Meana, A.; García-Palencia, P.; Higes, M. Natural infections of Nosema ceranae in European honey bees. J. Apic. Res. 2006, 47, 230-233. [CrossRef]

56. Fries, I.; Chauzat, M.-P.; Chen, Y.-P.; Doublet, V.; Genersch, E.; Gisder, S.; Higes, M.; McMahon, D.P.; Martín-Hernández, R.; Natsopoulou, M.; et al. Standard methods for Nosema research. J. Apic. Res. 2013, 52, 1-28. [CrossRef]

57. Cantwell, G. Standard methods for counting Nosema spores. Am. Bee J. 1970, 110, 222-223.

58. Bailey, L. The Epidemiology and Control of Nosema Disease of the Honey-bee. Ann. Appl. Biol. 1955, 43, 379-389. [CrossRef]

59. Otterstatter, M.C.; Thomson, J.D. Contact networks and transmission of an intestinal pathogen in bumble bee (Bombus impatiens) colonies. Oecologia 2007, 154, 411-421. [CrossRef]

60. Dussaubat, C.; Sagastume, S.; Gómez-Moracho, T.; Botías, C.; García-Palencia, P.; Martín-Hernández, R.; Le Conte, Y.; Higes, M. Comparative study of Nosema ceranae (Microsporidia) isolates from two different geographic origins. Vet. Microbiol. 2013, 162, 670-678. [CrossRef]

61. Kafadar, K.; Koehler, J.R.; Venables, W.N.; Ripley, B.D. Modern Applied Statistics with S-Plus, 4th ed.; Springer: New York, NY, USA, 2002; Volume 53, ISBN 038795457.

62. Akaike, H. Prediction and Entropy. In A Celebration of Statistics; Springer Science and Business Media LLC: New York, NY, USA, 1985; pp. 1-24.

63. Therneau, T.M.; Grambsch, P.M. Modeling Survival Data: Extending the Cox Model; Springer: New York, NY, USA, 2000; ISBN 0387987843.

64. Vaudo, A.D.; Patch, H.M.; Mortensen, D.A.; Tooker, J.F.; Grozinger, C.M. Macronutrient ratios in pollen shape bumble bee (Bombus impatiens) foraging strategies and floral preferences. Proc. Natl. Acad. Sci. USA 2016, 113, E4035-E4042. [CrossRef]

65. Kraus, S.; Gómez-Moracho, T.; Pasquaretta, C.; Latil, G.; Dussutour, A.; Lihoreau, M. Bumblebees adjust protein and lipid collection rules to the presence of brood. Curr. Zool. 2019, 65, 437-446. [CrossRef] [PubMed]

66. Ruedenauer, F.A.; Raubenheimer, D.; Kessner-Beierlein, D.; Grund-Mueller, N.; Noack, L.; Spaethe, J.; Leonhardt, S.D. Best be(e) on low fat: Linking nutrient perception, regulation and fitness. Ecol. Lett. 2020, 23, 545-554. [CrossRef] [PubMed]

67. Di Pasquale, G.; Salignon, M.; Le Conte, Y.; Belzunces, L.P.; Decourtye, A.; Kretzschmar, A.; Suchail, S.; Brunet, J.-L.; Alaux, C. Influence of Pollen Nutrition on Honey Bee Health: Do Pollen Quality and Diversity Matter? PLoS ONE 2013, 8, e72016. [CrossRef] [PubMed]

68. Basualdo, M.; Barragán, S.; Antúnez, K. Bee bread increases honeybee haemolymph protein and promote better survival despite of causing higher Nosema ceranae abundance in honeybees. Environ. Microbiol. Rep. 2014, 6, 396-400. [CrossRef] [PubMed]

69. Mohr, K.I.; Tebbe, C.C. Diversity and phylotype consistency of bacteria in the guts of three bee species (Apoidea) at an oilseed rape field. Environ. Microbiol. 2006, 8, 258-272. [CrossRef]

70. Wittner, M.; Weiss, L. The Microsporidia and Microsporidiosis; Weiss, L.M., Wittner, M., Eds.; American Society of Microbiology: Washington, DC, USA, 1999; ISBN 9781555811471.

71. Fleming, J.C.; Schmehl, D.R.; Ellis, J.D. Characterizing the Impact of Commercial Pollen Substitute Diets on the Level of Nosema spp. in Honey Bees (Apis mellifera L.). PLoS ONE 2015, 10, e0132014. [CrossRef]

72. Otti, O.; Schmid-Hempel, P. Nosema bombi: A pollinator parasite with detrimental fitness effects. J. Invertebr. Pathol. 2007, 96, 118-124. [CrossRef]

73. Trillo, A.; Brown, M.J.F.; Vilà, M. Prevalence of Nosema microsporidians in commercial bumblebees (Bombus terrestris) is not related to the intensity of their use at the landscape scale. Apidologie 2019, 50, 234-242. [CrossRef]

74. Bunning, H.; Bassett, L.; Clowser, C.; Rapkin, J.; Jensen, K.; House, C.M.; Archer, C.R.; Hunt, J. Dietary choice for a balanced nutrient intake increases the mean and reduces the variance in the reproductive performance of male and female cockroaches. Ecol. Evol. 2016, 6, 4711-4730. [CrossRef]

75. Bunning, H.; Rapkin, J.; Belcher, L.; Archer, C.R.; Jensen, K.; Hunt, J. Protein and carbohydrate intake influence sperm number and fertility in male cockroaches, but not sperm viability. Proc. R. Soc. B Biol. Sci. 2015, 282, 20142144. [CrossRef]

76. Rapkin, J.; Jensen, K.; Archer, C.R.; House, C.M.; Sakaluk, S.K.; Del Castillo, E.; Hunt, J. The Geometry of Nutrient Space-Based Life-History Trade-Offs: Sex-Specific Effects of Macronutrient Intake on the Trade-Off between Encapsulation Ability and Reproductive Effort in Decorated Crickets. Am. Nat. 2018, 191, 452-474. [CrossRef] [PubMed]

77. Lee, K.P.; Simpson, S.J.; Clissold, F.J.; Brooks, R.; Ballard, J.W.O.; Taylor, P.W.; Soran, N.; Raubenheimer, D. Lifespan and reproduction in Drosophila: New insights from nutritional geometry. Proc. Natl. Acad. Sci. USA 2008, 105, 2498-2503. [CrossRef] [PubMed]

78. Reddiex, A.J.; Gosden, T.P.; Bonduriansky, R.; Chenoweth, S.F. Sex-Specific Fitness Consequences of Nutrient Intake and the Evolvability of Diet Preferences. Am. Nat. 2013, 182, 91-102. [CrossRef] [PubMed]

79. Jensen, K.; McClure, C.; Priest, N.K.; Hunt, J. Sex-specific effects of protein and carbohydrate intake on reproduction but not lifespan in Drosophila melanogaster. Aging Cell 2015, 14, 605-615. [CrossRef] [PubMed]

80. Semaniuk, U.; Feden'Ko, K.; Yurkevych, I.S.; Storey, K.B.; Simpson, S.J.; Lushchak, O. Within-diet variation in rates of macronutrient consumption and reproduction does not accompany changes in lifespan in Drosophila melanogaster. Entomol. Exp. Appl. 2018, 166, 74-80. [CrossRef] 
81. Fanson, B.G.; Weldon, C.W.; Pérez-Staples, D.; Simpson, S.J.; Taylor, P.W. Nutrients, not caloric restriction, extend lifespan in Queensland fruit flies (Bactrocera tryoni). Aging Cell 2009, 8, 514-523. [CrossRef]

82. Maklakov, A.A.; Simpson, S.J.; Zajitschek, F.; Hall, M.D.; Dessmann, J.; Clissold, F.; Raubenheimer, D.; Bonduriansky, R.; Brooks, R.C. Sex-Specific Fitness Effects of Nutrient Intake on Reproduction and Lifespan. Curr. Biol. 2008, 18, 1062-1066. [CrossRef]

83. Ponton, F.; Wilson, K.; Holmes, A.; Raubenheimer, D.; Robinson, K.L.; Simpson, S.J. Macronutrients mediate the functional relationship between Drosophila and Wolbachia. Proc. R. Soc. B Biol. Sci. 2015, 282, 20142029. [CrossRef]

84. Altaye, S.Z.; Pirk, C.W.W.; Crewe, R.M.; Nicolson, S.W. Convergence of carbohydrate-biased intake targets in caged worker honeybees fed different protein sources. J. Exp. Biol. 2010, 213, 3311-3318. [CrossRef]

85. Zheng, H.-Q.; Lin, Z.-G.; Huang, S.-K.; Sohr, A.; Wu, L.; Chen, Y.P. Spore Loads May Not be Used Alone as a Direct Indicator of the Severity of Nosema ceranae Infection in Honey Bees Apis mellifera (Hymenoptera: Apidae). J. Econ. Entomol. 2014, 107, 2037-2044. [CrossRef]

86. Van Der Zee, R.; Gómez-Moracho, T.; Pisa, L.; Sagastume, S.; García-Palencia, P.; Maside, X.; Bartolomé, C.; Martín-Hernández, R.; Higes, M. Virulence and polar tube protein genetic diversity of Nosema ceranae (Microsporidia) field isolates from Northern and Southern Europe in honeybees (Apis mellifera iberiensis). Environ. Microbiol. Rep. 2014, 6, 401-413. [CrossRef] [PubMed] 